Doi: HTTPS://DOI.ORG/10.23910/IJEP/2018.5.4.0275

\title{
Prosopis glandulosa Torr. A Multipurpose Tree from Arid and Semiarid Lands of Mexico
}

\author{
Rahim Foroughbakhch*, Marco Antonio Guzman Lucio, Marco Antonio Alvarado Vazquez
}

AutonomusUniversity of Nuevo Leon, BiologicalScienceFaculty, San Nicolas de los Garza, N.L., Mexico

\section{Corresponding Author}

Rahim Foroughbakhch

e-mail: rahim.forough@gmail.com

\author{
Article History \\ Article ID: IJEP0275 \\ Received in $08^{\text {th }}$ October, 2018 \\ Received in revised form $12^{\text {th }}$ November, 2018 \\ Accepted in final form $21^{\text {st }}$ November, 2018
}

\begin{abstract}
In the present study the multipurpose characterization of the mesquite scrub of the northeast of Mexico was carried out and its productive potential for wood was evaluated. Ten sampling sites were randomly selected based on cartographic material where mesquite was the dominant species. In each one of the sites the minimum area of sampling was determined, for the evaluation of the arboreal and shrub layers. In each area all individuals of the present species were registered, measuring its height and crown projection for the determination of the parameters of density, canopy, frequency and importance value for each species. The physiognomy of the studied sites was dominated by shrub and arboreal plants where the most outstanding vegetation by its height, density and cover was Prosopis glandulosa. The total floral diversity found was 160 taxa belonging to 46 families. The most common species in addition to $P$. glandulosa were Ruellia nudiflora, Opuntia leptocaulis, Celtis pallida, Opuntia engelmannii, Dyschoriste decumbens, Acacia rigidula, Castela texana, Karwinskia humboldtiana, Ziziphus obtusifolia, Acleisanthes obtusa and Tridens muticus. The accumulated average cover layer was $203.20 \%$, being the shrub layer with greatest vegetative cover with $85.6 \%$. The greatest importance values (IV)in the shrub and arboreal layers for $P$. glandulosa were 11.12 and $80.31 \%$ respectively. In the arboreal layer, $P$. glandulosa reached the greater percentage in all the parameters, dominating completely the stratum. The wood production average plant ${ }^{-1}$ and ha- was $0.0929 \mathrm{~m}^{3}$ and $38.25 \mathrm{~m}^{3}$ respectively. The estimation of the volume of wood had a strong relationship with the variables of basal diameter and crown projection.
\end{abstract}

Keywords: Mesquite, multipurpose tree, wood potential

\section{Introduction}

The shrub and woodland communities established in northeastern Mexico and southern Texas, USA, constitutes the most common land use in this area. However, it is being degraded by the exploitation and extraction of its woody components, specially from plants of the genus Prosopis, Helietta, Condalia and some Acacia species. Prosopis glandulosa (honey mesquite) and $P$. laevigata are the most important and exploited components in the northeastern woodland of Mexico (Rzedowski, 1988; Pasiecznik et al., 2001).

Despite specimens of the Prosopis genus are distributed throughout the entire world its principal center of origin has been located in South America, with 42 species. North America counts with 10 species, nine of them native from Mexico. Of these species, $P$. glandulosa is a species that distributes from the south of USA, particularly Texas State, to the northeast of Mexico (Estrada et al., 2004, 2005), showing so much fast dispersion and expansion characteristics that that it is considered as an invader plant in some rangelands of south USA (Boutton et al., 1998; Acevedo, 2012).

According to the World Bank (Vender-Plas, 1995), the charcoal production is a practice that hardly would be eradicated because it constitutes an important income to rural families. Therefore, information is needed about mesquite growth variables to record its production capacity on the area and so far its structural change through time (Nyland, 2002). These records can help scientists in the recognition and detection of ecological changes that might be occurring in the plant community (Dieguez et al., 2003, Evans et al., 2013).

Considering the preceding the present study was made to know the growth characteristics and the population structure of mesquite trees in natural conditions as a contribution to build up the basis for the implementation of a management program of this plant resource with the purpose to guarantee its sustainable exploitation (Clark and Kellner, 2012).

\section{Materials and Methods}

\subsection{Study Area}

The study was carried out in northeast of Mexico, which is located between $23^{\circ} 10^{\prime} 27^{\prime \prime}$ and $27^{\circ} 46^{\prime} 06^{\prime \prime}$ of North latitude and between $98^{\circ} 26^{\prime} 24^{\prime \prime}$ and $101^{\circ} 13^{\prime} 55^{\prime \prime}$ West longitude with a territorial extension of $65,103 \mathrm{~km}^{2}$. The Tropic of Cancer line 
located in the parallel $23^{\circ} 27^{\prime} \mathrm{N}$ crossing the State in the south.

The climate of northeastern Mexico is in extreme contrasting. The hot and dry climate predominate and it is associated with semi-arid or semi-dry of the Kopen classification. Most of the year it is very hot, mainly in the plains, since at the mountain regions the altitude attenuates the warm temperatures.

The mean annual temperature is $22.3{ }^{\circ} \mathrm{C}$ with a large difference between winter and summer $\left(-2.3\right.$ to $\left.41.1^{\circ} \mathrm{C}\right)$. Hail and frosts usually occur every year even after the beginning of the growing season in March.The long-term mean annual precipitation values vary from $380 \mathrm{~mm}$ (arid zones) to $749 \mathrm{~mm}$ (semiarid zones) with two peaks in late May and July-September and drought periods in June and winter (Foroughbakhch, 1992; Reid et al., 1987).

The soils of the region are basically stony of Upper Cretaceous siltstone, these soils are classified as rendzine, vertisoils, feozem and castañozem with low organic matter content and low levels of phosphorus and nitrogen. Underground water is hard but not saline.

\subsection{Vegetation structure}

Once the sites were located, the minimum area in each one of them was considered with the purpose to obtain a represented vegetal composition employing the technique of the nestedsample (Muller-Dombois and Ellinberg, 1974). The species occurring in each subsample were registered and the minimum area of sampling was determined as the surface where at least $95 \%$ of the species of the vegetal community were contained.

Permanent site sampling along each mesquitecommunity was made at random. The average distance among the sites varied according to the vegetative composition and the heterogeneity degree.

In each site all the arboreal and shrub species were identified. Measurements were made of height $(\mathrm{m})$, base diameter $(\mathrm{cm})$, and the crown projection area $\left(\mathrm{m}^{2}\right)$ which was obtained to determine the two perpendicular diameters of each plant, dominance and frecuency (Avery and Burkhard, 2002). The absolute values for each species were converted to relative values to derive the importance index (Graf and Sayagues, 2000).

\subsection{Statistical analysis}

Statistical analysis was computed using the SPSS (version 19.0) statistical package. A Duncan test was applied to the mean values of growing and production parameters (Zar, 2006) in order to gather sites with certain similar characteristics. The regression and correlation models were applied to the increment parameters and firewood volume production. Three regression models were used and the selection of the best matching model was made based on the coefficient of determination value $\left(r^{2}\right)$.

\section{Results and Discussion}

\subsection{Structure, diversity and similarity of the studied communities}

A total diversity of 160 taxa pertaining to 46 families were found. The families with greater number of taxa were Poaceae, Asteraceae and Cactaceae with 19, 18 and 14 taxa respectively, followed by Fabaceae with nine taxa and Euphorbiaceae and Acanthaceae with eight in both cases (Figure 1); the rest of the families mostly presented less than three taxa and 23 of them were represented by a single taxon. The most common species, considering than they were present in all the sampled communities were Ruellia nudiflora, Opuntia leptocaulis, Celtis pallida and Prosopis glandulosa. Other species also common in the study sites are Opuntia engelmannii, Dyschoriste decumbens, Acacia rigidula, Castela texana, Karwinskia humboldtiana, Ziziphus obtusifolia, Acleisanthes obtusa and Tridens muticus.

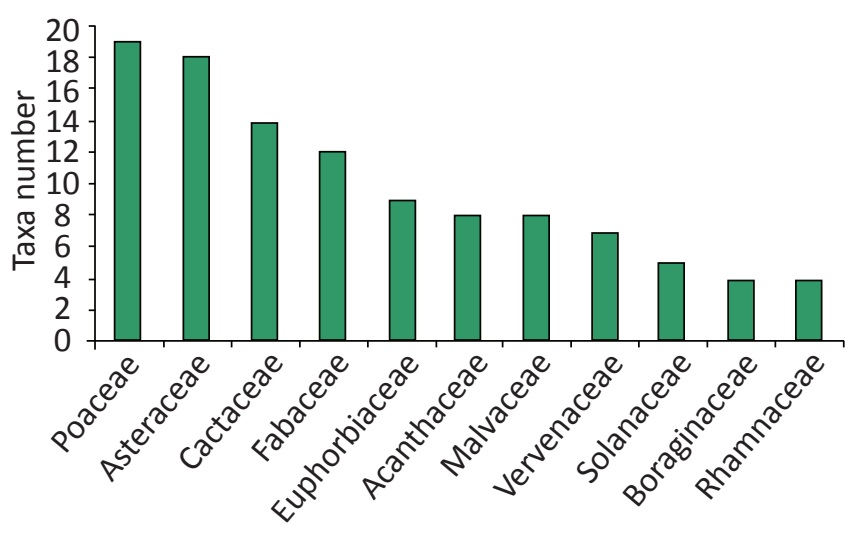

Families

Figure 1: Families with higher diversity in the mesquite scrub and woodland studied

It is important to emphasize that during the study the presence of two endangered species were detected in compliance with the Official Mexican Norm NOM-059-SEMARNAT-2001 (2002). The species were Echinocereus poselgeri (Cactaceae) that has the status "subject to special protection" and Manfreda longiflora (Agavaceae) with "threatened status". In both cases, deforestation and extensive cattle ranch are the factors that contribute greater negative impact and inflict loss and deterioration of their habitat.

In the Figure 2 the participation in relative terms of Prosopis glandulosa as a component of the shrub and arboreal strata of the studied communities is shown.

$P$. glandulosa displayed little cover in the herbaceous layer going from its absence in five of the studied sites to a maximum of the $1,02 \%$ of the total stratum cover. In the shrub layer its presence is far more noticeable although there are enormous variations between sites (from 38.46 to $b$ 49.73). Finally, in the arboreal layer, P. glandulosa it displayed percentages of cover from 90 to $100 \%$ in most of the sites, 

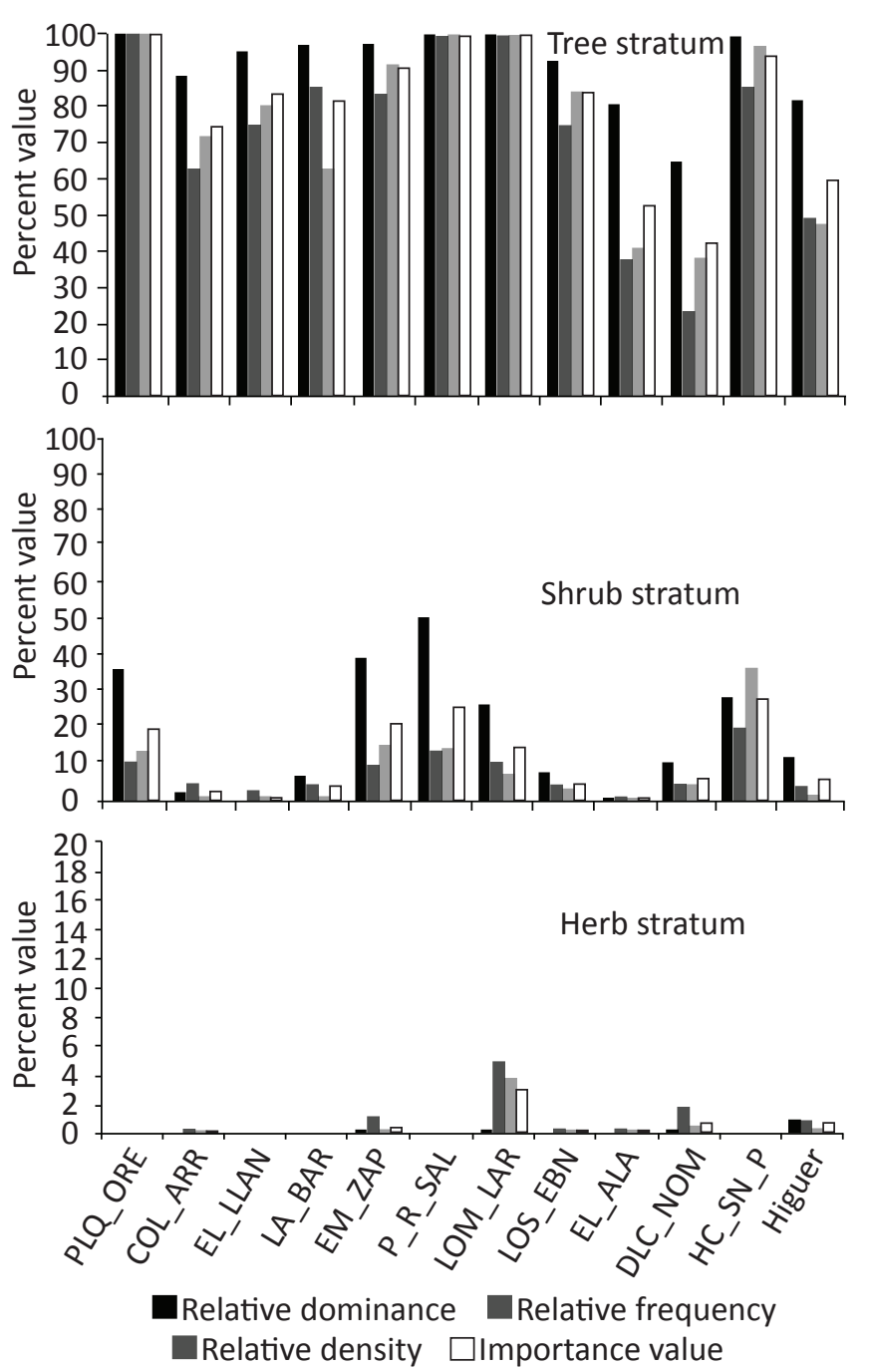

Figure 2: Participation of Prosopis glandulosa in the dominance, frequency, density and importance value in each stratum of the studied communities

which is reasonable since in several sites it constitutes the only species of this layer. In other sites where richness is low and present greater diversity, the density of other species is low and as aconsequence its cover value is also low (Table 3 and Figure 3).

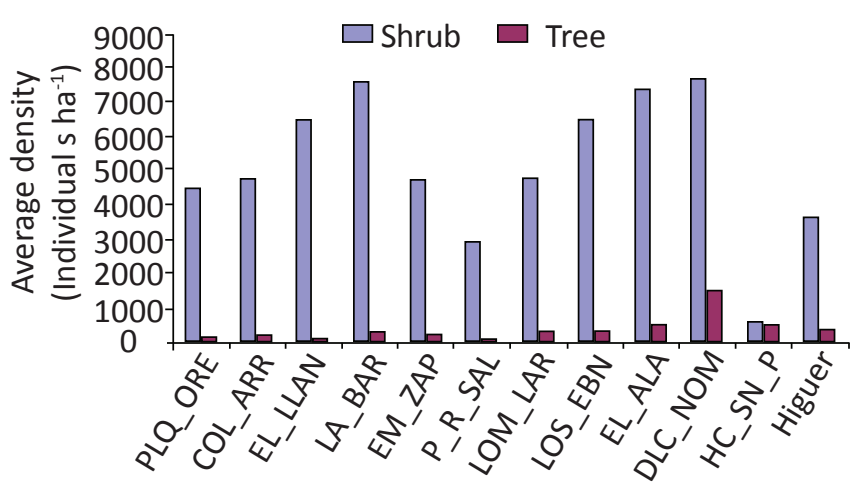

Figure 3: Mean density per site in the shrub and tree strata

\subsection{Frecuency, density and importance value}

In the Table 1, the species with higher frecuency for this stratum can be appreciated. Prosopis glandulosa is the species most frequently occurring in the sites of study and it was present in all of them. Moreover, this species was the only arboreal element was second in rank between sites despite occurring in six of $(60 \%)$ the localities. On the other hand, Acacia wrightii and Celtis pallida were present in 4 sites (33.33\%). The rest of the species presented smaller frequencies and even three species (Acacia farnesiana, Cercidium sp. and Havardia pallens) appeared only in one community. Concerning the relative frequencies of $P$. glandulosa within communities it reached values superior to $75 \%$ in most of the communities and logically in three of them the frequency reached $100 \%$.

The average number of individuals per hectare in the arboreal stratum was 412.74 , with a minimum value of 120 and a maximum of 566.67 (Figure 3). As for the general average density by taxa we found that the greater value was reached by Havardia pallens with 540 individuals ha ${ }^{-1}$. Nevertheless, this result is not representative of all the communities. On the other hand, $P$. glandulosa was present in the arboreal stratum in all the communities and showed an average density between them of 261.07 individuals $\mathrm{ha}^{-1}$, reaching as high as 600 individuals ha-1 and a minimum of 120 .

The average vegetation cover of the arboreal stratum was $80.81 \%$, with a maximum of $154.86 \%$ and a minimum of $25.75 \%$. As for the individual cover by taxa, we have found that the greatest values of cover in this stratum were obtained for $P$. glandulosa in all the sites. After P. glandulosa, the species with greater cover in rank were Havardia pallens with $20.51 \%$ and Acacia wrightii with $12.39 \%$.

P. glandulosais the species that presents the greatest IV of the arboreal stratum between all the communities with an average of 80.31; followed by Havardia pallens and Acacia wrightii which showed average values of 20.72 and 14.00 respectively (Table 2 ). As for the IV to the inside of the arboreal stratum at each community the higher value was obtained by $P$. glandulosa in all the communities. In three of the communities the IV reached $100 \%$; in other six, IVs higher than $75 \%$ were obtained while in the three of the remaining communities IV exceeded the $40 \%$. The species with greater IVs after $P$. glandulosa were H. pallens, Acacia wrightii and A. rigidula with IVs of 20.72, 18.62 and 18.06 respectively.

\subsection{Wood volume of Prosopis glandulosa}

One of the most valuable dasometric variables for the estimation of the volume of wood in feet is the basal diameter (bd) of the plant. In Table 3 it is shown the total wood production ha- ${ }^{-1}$ and class $^{-1}$ of diameter for trunks and branches with diameters greater to $5 \mathrm{~cm}$. It can be noticed there that the greater volume of wood in feet ha ${ }^{-1}$ with a total $126.47 \mathrm{~m}^{3} \mathrm{ha}^{-1}$, which around $40 \%$ comes from trunks and branches with diameters of $10-15 \mathrm{~cm}$. The greater volume comes from trunks with diameters greater than $20 \mathrm{~cm}$. In the 


\begin{tabular}{lccccc}
\hline \multicolumn{4}{l}{ Table 1: Species with higher frequency $(\%)$ in the herbaceous, shrub and arboreal strata in the studied communities } \\
\hline Herb & Freq & Shrub & Frec & Tree & Freq \\
\hline Opuntia leptocaulis & 100.00 & Celtis pallida & 100.00 & Prosopis glandulosa & 100.00 \\
Ruellia nudiflora & 100.00 & Opuntia leptocaulis & 100.00 & Acacia rigidula \\
Dyschoriste decumbens & 91.67 & Prosopis glandulosa & 100.00 & Acacia wrightii \\
Acleisantes obtusa & 83.33 & Opuntia engelmannii & 91.67 & Celtispallida & 33.33 \\
Tridens muticus & 83.33 & Acacia rigidula & 83.33 & Bumeliacelastrina & 16.67 \\
Mammillaria heyderi & 75.00 & Castela texana & 83.33 & Condaliahookeri & 16.67 \\
Bouteloua trifida & 66.67 & Karwinskia humboldtiana & 83.33 & Porlieria angustifolia & 16.67 \\
Malvastrum coromandelianum & 66.67 & Ziziphus obtusifolia & 83.33 & Acacia farnesiana & 8.33 \\
Rivina humilis & 66.67 & Acacia wrightii & 75.00 & Cercidium sp. \\
Setaria macrostachya & 66.67 & Porlieria angustifolia & 75.00 & Havardia pallens & 8.33 \\
\hline
\end{tabular}

Table 2: Species with higher average importance values (IV) in the herb, shrub and arboreal strata from the studied communities

\begin{tabular}{lclll}
\hline Herbaceous & IV & Srub & IV & Arboreal \\
\hline Ruellian udiflora & 14.30 & Opuntia leptocaulis & 14.31 & Prosopis glandulosa \\
Opuntia leptocaulis & 8.14 & Opuntia engelmannii & 10.41 & Havardia pallens \\
Ruellia sp. & 7.69 & Prosopis glandulosa & 9.87 & Acacia wrightii \\
Calyptocarpus vialis & 7.07 & Celtis pallida & 9.65 & Acacia rigidula \\
Bouteloua trifida & 6.41 & Paulothamus spinescens & 8.89 & Pithecellobium flexicaule \\
Oxalis dichondra efolia & 6.20 & Acacia rigidula & 7.51 & Celtis pallida \\
Tridensmuticus & 5.83 & Ziziphus obtusifolia & 7.01 & Condalia hookeri \\
Lantana camara & 5.25 & Eupatorium sp. & 5.76 & Bumelia celastrina \\
Dyschoriste decumbens & 5.11 & Karwinskia humboldtiana & 5.57 & Acacia farnesiana \\
Setaria sp. & 4.92 & Castela texana & 5.47 & Cercidium sp. \\
\hline
\end{tabular}

For the Srub and herbaceous strata only those species occurring in at least $25 \%$ of the sites were considered. In the arboreal stratum all the species were considered

Table 3: Mean values for firewood volume production, height, basal diameter and canopy per plant of Prosopisglandulosa in 10 sampled sites

\begin{tabular}{llcccc}
\hline $\begin{array}{l}\text { Site } \\
\text { No. }\end{array}$ & $\begin{array}{l}\text { Mesquite } \\
\left.\text { Density (trees ha }{ }^{-1}\right)\end{array}$ & $\begin{array}{c}\text { Firewood volume produc- } \\
\text { tion plant }{ }^{-1}\left(\mathrm{~m}^{3}\right)\end{array}$ & $\begin{array}{c}\text { Plant Height } \\
(\mathrm{m})\end{array}$ & $\begin{array}{c}\text { Plant Canopy } \\
\left(\mathrm{m}^{2}\right)\end{array}$ & $\begin{array}{c}\text { Basal Diameter } \\
(\mathrm{cm})\end{array}$ \\
\hline 1 & 470 & $2.040 \pm 0.388 \mathrm{e}^{*}$ & $3.73 \pm 0.15 \mathrm{e}^{*}$ & $9.83 \pm 1.31 \mathrm{~d}^{*}$ & $14.13 \pm 1.24 \mathrm{~b}^{*}$ \\
2 & 200 & $15.860 \pm 2.786 \mathrm{abcd}$ & $6.19 \pm 0.34 \mathrm{abcd}$ & $31.92 \pm 4.38 \mathrm{abc}$ & $38.05 \pm 2.77 \mathrm{a}$ \\
4 & 233 & $11.702 \pm 2.321 \mathrm{abcd}$ & $6.01 \pm 0.60 \mathrm{abcd}$ & $33.43 \pm 7.40 \mathrm{abc}$ & $29.82 \pm 4.45 \mathrm{ab}$ \\
5 & 366 & $5.886 \pm 1.601 \mathrm{cde}$ & $3.79 \pm 0.20 \mathrm{cde}$ & $14.77 \pm 2.17 \mathrm{~cd}$ & $17.01 \pm 1.85 \mathrm{~b}$ \\
6 & 410 & $3.775 \pm 0.939 \mathrm{de}$ & $3.50 \pm 0.20 \mathrm{de}$ & $20.22 \pm 4.01 \mathrm{bcd}$ & $15.48 \pm 1.55 \mathrm{~b}$ \\
7 & 430 & $3.930 \pm 0.712 \mathrm{de}$ & $4.21 \pm 0.17 \mathrm{de}$ & $16.41 \pm 1.75 \mathrm{~cd}$ & $17.16 \pm 1.31 \mathrm{~b}$ \\
8 & 350 & $6.240 \pm 1.278 \mathrm{bcde}$ & $4.17 \pm 0.28 \mathrm{abcd}$ & $16.91 \pm 2.41 \mathrm{~cd}$ & $21.06 \pm 2.01 \mathrm{ab}$ \\
9 & 260 & $22.173 \pm 3.692 \mathrm{abc}$ & $6.22 \pm 0.35 \mathrm{abc}$ & $37.34 \pm 5.51 \mathrm{abc}$ & $32.46 \pm 3.71 \mathrm{a}$ \\
10 & 560 & $5.941 \pm 1.416 \mathrm{bcde}$ & $5.48 \pm 0.22 \mathrm{bcde}$ & $15.16 \pm 2.13 \mathrm{~cd}$ & $14.08 \pm 1.08 \mathrm{~b}$ \\
11 & 550 & $22.988 \pm 8.919 \mathrm{ac}$ & $6.46 \pm 0.30 \mathrm{ac}$ & $39.23 \pm 9.30 \mathrm{ab}$ & $18.42 \pm 2.31 \mathrm{~b}$ \\
Average & $9.29 n d$. Error & $9.296 \pm 1.330$ & $486.47 \pm 8.36$ & $23.03 \pm 1.58$ & $19.47 \pm 0.64$ \\
\hline
\end{tabular}

* Values followed by the same letters are not significantly different at the $5 \%$ level 
communities with minor wood in feet production the greater production corresponded to trunks or branches of 5-10 cm, although some of them display important densities but mostly showing small bd.

\section{Conclusion}

The average density of individuals was 554.87 specimens ha $^{-1}$ considering the individuals of all basal diameters present in the shrub and arboreal layers, whereas the average density considering only those individuals with potential advantage for wood exploitation (basal diameters greater than $5 \mathrm{~cm}$ ) was 382.90 individuals ha-1. The average wood production per plant among all the sites of study was $0.0929 \mathrm{~m}^{3}$, as for the wood production an average of $38,25 \mathrm{~m}^{3} \mathrm{ha}^{-1}$ was found.

\section{References}

Acevedo, M.A., Marcano, M., Fletcher, R.J., 2012. A diffusive logistic growth model to describe forest recovery. Ecol. Model 244, 13-19.

Avery, E.T., Burkhart, H., 2002. Forest measurements.Fifth edition. Mc. Graw Hill. New York, 144-167.

Boutton, T.W., Archer, S.R., Midwood, A.J., Zitzer, S.F., Bol, R., Nordt, L.C., Boutton, E.F., 1998. Delta 3C values of soil organic carbon and their use in documenting vegetation change in a subtropical savanna ecosystem. Geoderma, 82, 1-3, 5-41.

Clark, D.B., Kellner, J.R., 2012. Tropicalforest mass estimation and the fallacyofmis placed concreteness. Journal of Vegetation Science23(6), 1191-1196. doi:10.1111/ j.1654-1103.2012.01471.x.

De la Vega, C.F., Ramirez, M.H., Trevino, J.L., 1994. Dendrometría. Universidad Autonoma de Chapingo, 23-60.

Dieguez, A.U., Barrio, A.M., Castedo, D.F., Ruiz, A.D., Alvarez, M.F., Alvarez, J.G., Rojo, A.A., 2003. Dendrometria. Mundi prensa ediciones. Fundacion Conde del Valle de Salazar. E. T. S. I. Montes 31-146; 243-249.

Estrada, C.E., Yen, M.C., Delgado, S.A., Villarreal, Q.J., 2004. Legumbres del centro del estado de Nuevo León, Mexico. Anales del Instituto de Biologia. Universidad Nacional Autonoma de Mexico. Serie Botanica 75(1), 73-85.

Estrada, C.A.E., 2005. Legumbres del Estado de Nuevo Leon, Mexico. In: Topicos selectos de Botanica 2. (Eds) Foroughbakhch, R., Alvarado, M.A., Torres, T.E., Marroquin, J.S., Departamento de Botanica. Facultad de Ciencias Biologicas. Universidad Autonoma de Nuevo Leon, 73-94.

Evans, A.M., Perschel, R.T., Kittler, B.A., 2013. Overview of forest biomass harvesting guidelines. Journal of Sustainable For 32(1-2), 89-107. doi: 10.1080/10549811.2011.651786

Ffolliott, P.F.,Thames, J.L., 1982. Manual sobre taxonomía de Prosopis en Mexico, Peru y Chile. Universidad de Arizona. Tucson, Arizona. E.U.A. Organizacion de las Naciones Unidas para la Alimentacion y Agricultura.

Foroughbakhch, R., 1992. Establishment and growth potential of fuelwood species in northeastern Mexico. Agroforestry Systems, 19 (2), 95-108.

Franco, L.J., de la Cruz, A.G., Cruz, G.A., Rocha, R.A., Navarrete, S.N., Flores, M.G., Miranda, K.E., Sanchez, C.S., Abarca, L.G.,Bedia, S.C., 2001. Manual de ecologia. Ed. Trillas. Sexta Reimpresion, 266.

Graf, E., Sayagues, L., 2000. Muestreo de vegetación. Unidad de sistemas ambientales. Facultad de Agronomía. Universidad de la Republica, 41.

Miranda, F., Hernandez, X.E., 1963. Los tipos de vegetacion de México y su clasificacion. Soc. Bot. De Mexico 28, 178.

Mostacedo, B., Fredericksen, T.S., 2000. Manual de metodos basicos de muestreo y analisis en ecología vegetal. Proyecto de Manejo Forestal Sostenible (BOLFOR) Santa Cruz Bolivia. Ed. Daniel Nash. Bolivia, 87.

Mueller-Dombois, D., Ellenberg, H., 1974. Aims and methods of vegetation ecology. Wiley\&Sons Inc, 45-54 and 93-120.

Nyland, R.D., 2002. Silviculture. Concepts and applications. Second Edition.Mc. Graw Hill, 189-212.

Pasiecznik, N.M., Felker, P., Harris, J.C., Harsh, L.N., Cruz, G., Tewari, J.C., Cadoret, K., Maldonado, L.J., 2001. The Prosopis juliflora - Prosopis pallida Complex: A

Reid, N., Stafford, S.M., Bayer-Munzel, P., Marroquin, J., 1987. A research strategy for ecological survey: Floristics and lands use in the tamaulipanthornscrub, northeastern Mexico. In: Strategies for classification and management of native vegetation for food production in arid zones. General TechnicalReport RM 150: 32-38, Tucson, Arizona, USA.

Rojas, P., 1965. Generalidades sobre la vegetacion del estado de Nuevo Leon y datos acerca de su flora. Tesis Doctoral. Facultad de Ciencias. Universidad Nacional Autónoma de Mexico. Mexico, D.F., 199.

Rzedowski, J., 1988. Analisis de la distribucion geografica del complejo Prosopis (Leguminosae, Mimosoideae) en Norteamérica. Acta Botánica Mexicana, 3, 7-19.

Vander- Plas, R., 1995. Energy issues. Burning charcoal issues. World Bank Group.

Salvador, F.J., Alvarez, S.J., 2004. Flora y vegetacion. En: Tecnicas de muestreo para manejadores de recursos naturales, Bautista, F., Delfin, H., Palacio, J., Delgado, M., Del, C. (Eds.), Universidad Autonoma de Mexico, Universidad Autonoma de Yucatan, Consejo Nacional de Ciencia y Tecnologia, Instituto Nacional de Ecología. 1era. Ed. Mexico, 303-327.

Secretaria de Medio Ambiente y Recursos Naturales (Semarnat). 2002. NORMA Oficial Mexicana NOM-059ECOL-2001, Proteccion ambiental-Especies nativas de Mexico de flora y fauna silvestres. Categorias de riesgo y especificaciones para su inclusion, exclusion o cambio. Lista de especies en riesgo. Diario Oficial de la Federacion. Segunda seccion. 6 de marzo de 2002. Mexico, D.F., 1-81.

Zar, H.J., 1999. Biostatistical analysis. 4a. Ed. Prentice Hall. New Jersey, 99-103, 177-195 y 208-214. 